\title{
MEASURING THE SUCCESS OF APPROACHES TO COMMUNITY-BASED ARMED GROUPS
}

\author{
MORITZ SCHUBERTH
}

\section{COMMUNITY-BASED ARMED GROUPS SERIES}

\section{${ }^{6}$ It is difficult to measure results of approaches to CBAGs, attribute them to specific interventions, and evaluate their impacts."}

\section{FAST FACTS}

$\rightarrow$ Over recent decades, numerous national and international actors working in fragile, conflict-affected, and post-conflict states have developed a set of standard tools to approach CBAGs.

$\rightarrow$ Better metrics are needed to measure the success of interventions and to more accurately eva-

luate their impacts.

$\rightarrow$ Although the overall goal of approaches towards CBAGs is an improvement in community security for the populations living in areas where CBAGs are present, each approach has its specific objective.

\section{Introduction}

Community-Based Armed Groups (CBAGs) are armed groups that are embedded within communities and whose delineation can be defined by territory, blood ties, or shared identities; this definition includes vigilantes, militias, and criminal gangs. ${ }^{1}$ A recent RESOLVE research report has mapped how different intervening actors-governments, communities, civil society organizations, humanitarian and development agencies, and security providers-have approached the challenges posed by CBAGs in sub-Saharan Africa and how successful these approaches have been. ${ }^{2}$

1 Moritz Schuberth, "The Challenge of Community-based Armed Groups: Towards a Conceptualization of Militias, Gangs, and Vigilantes," Contemporary Security Policy 36, no. 2 (2015): 296-320.

2 Moritz Schuberth, Approaching Community-Based Armed Groups in Sub-Saharan Africa: Lessons Learned \& Measures of Success (Washington, DC: RESOLVE Network, 2019). 
One of the key findings from the report is that it is difficult to measure results of approaches to CBAGs, attribute them to specific interventions, and evaluate their impacts due to multiple confounding factors and overlapping interventions. This policy note offers recommendations on how to assess the success of different approaches to CBAGs, proposing a set of indicators that intervening actors could use to measure the progress of interventions in meeting their objectives.

\section{Relevance to Policy and Practice}

Over recent decades, numerous national and international actors working in fragile, conflictaffected, and post-conflict states have developed a set of standard tools to approach CBAGs. ${ }^{3}$ Approaches to CBAGs can be categorized as following three different logics: engagement, management, and transformation (EMT).

Engagement follows a short-term logic; actors pursuing this approach do so for instrumental reasons, that is, to ensure the safety of their own staff members while implementing their projects or to promote mediation and reduce violence within communities. Engagement refers, for instance, to humanitarian and development actors hiring armed clan-based militias to provide protection or to transport food to insecure areas in Somalia. ${ }^{4}$ Another example of engagement is provided by traditional community conflict resolution systems, such as barazas communautaires in eastern Democratic Republic of Congo. ${ }^{5}$

Management approaches follow a mid-term logic as actors envision a substantive change in targeted groups. Coercive management approaches involve security forces and heavy-handed measures to defeat CBAGs or incarcerate their members, for instance, militarized police raids against gangs in South Africa. ${ }^{6}$ Actors pursuing cooperative management approaches, by contrast, strive to alter the behavior and roles of CBAGs by negotiation, as happened with grands trafiquants in Mali; ${ }^{7}$ mediation, as in the Central African Republic between ex-Séléka rebels and anti-Balaka self-defense groups; ${ }^{8}$ or co-optation, as done in Nigeria with the Civilian Joint Task Force (CJTF). ${ }^{9}$

Transformation follows a long-term logic and refers to a set of approaches to replace the functions that CBAGs provide to their members, sponsors, and the communities they are nested in with an accountable state bound by the rule of law. Transformation addresses the root causes and structural conditions that led to the emergence of the CBAG ecosystem. This goal is difficult to

3 Jairo Munive and Finn Stepputat, "Rethinking Disarmament, Demobilization and Reintegration Programs," Stability: International Journal of Security \& Development 4, no. 1 (2015): Art. 48.

4 Joakim Gundel, Humanitarian Action in the New Security Environment: Policy and Operational Implications in Somalia and Somaliland (London: Overseas Development Institute, 2006).

5 Jean Chrysostome Kiyala, "Utilising a Traditional Approach to Restorative Justice in the Reintegration of Former Child Soldiers in the North Kivu Province, Democratic Republic of Congo," Africa Insight 46, no. 3 (2016): 33-50.

6 Guy Lamb, "Police Militarisation and the 'War on Crime' in South Africa," Journal of Southern African Studies 44, no. 5 (2018): 933-49.

7 Katrin Planta and Véronique Dudouet, Fit for Negotiation? Options and Risks in the Political Transformation of Non-conventional Armed Groups (Oslo: Norwegian Peacebuilding Resource Centre (NOREF), 2015).

8 Marie-Joëlle Zahar and Delphine Mechoulan, Peace by Pieces? Local Mediation and Sustainable Peace in the Central African Republic (New York: International Peace Institute, 2017).

9 Kyle Dietrich, "When We Can't See the Enemy, Civilians Become the Enemy" - Living Through Nigeria's Six-Year Insurgency (Washington, DC: Center for Civilians in Conflict, 2015). 
achieve because it requires lengthy commitments and buy-in from multiple actors. As an example, the UN stabilization missions in the Central African Republic, Democratic Republic of Congo, and Mali all employed a combination of security sector reform (SSR), disarmament, demobilization, and reintegration (DDR), and community violence reduction (CVR) programs, with varying degrees of success. ${ }^{10}$

Even though standard tools such as DDR and SSR have been applied in various settings and across circumstances, their effectiveness is regularly questioned. ${ }^{11}$ This is partly due to the difficulty of attributing the results of EMT approaches to specific interventions. Multiple actors typically implement projects with similar objectives simultaneously. External factors such as elections and natural disasters might influence the outcome of any given intervention. Better metrics are needed to measure the success of interventions and to more accurately evaluate their impacts. The following recommendations are aimed at improving measurements of success of approaches to CBAGs.

\section{Recommendations}

The desired results of approaches to CBAGs include a protective rather than predatory behavior vis-à-vis local communities; identification of all key stakeholders and coordination among implementing partners; respect for the principles of conflict sensitivity; and adherence of CBAGs to good governance standards and norms, such as human rights and the rule of law. Moreover, approaches should yield sustainable results that persist after funding for the intervention runs out. The following recommendations show how intervening actors can better measure the progress towards these objectives:

\section{Assessments}

\section{$\rightarrow$ Conduct context analysis}

Before deciding to intervene in areas with a high presence of CBAGs, it is essential to understand the nature of these groups and local power dynamics. In Haiti, for instance, the United Nations Stabilization Mission (MINUSTAH) attempted to deal with urban CBAGs in the same way as rural rebels in Central Africa even though the conflict environment was not conducive to such an endeavor. ${ }^{12}$ Therefore, programming initiatives should design and implement interventions only after thorough political economy analysis and evidence-based mapping of all local actors, in coordination with academics and practitioners knowledgeable of the terrain.

10 Robert Muggah and Chris O’Donnell, “Next Generation Disarmament, Demobilization and Reintegration," Stability: International Journal of Security \& Development 4, no. 1 (2015): Art. 30.

11 Paul Jackson, "Introduction: Second-Generation Security Sector Reform," Journal of Intervention and Statebuilding 12, no. 1 (2018): 1-10.

12 Moritz Schuberth, “Disarmament, Demobilisation and Reintegration in Unconventional Settings: The Case of MINUSTAH's Community Violence Reduction," International Peacekeeping 24, no. 3 (2017): 410-33. 


\section{$\rightarrow$ Conduct baseline study and impact evaluation.}

From the outset, intervening actors should plan for undertaking an impact evaluation after the intervention is completed. Rigorous impact assessment requires a thorough methodology that allows for testing underlying assumptions and causal relationships that underpin the intervention. Systematic baseline assessments and monitoring throughout the implementation phase are key to the success of an impact evaluation. Baseline assessments help to understand the environment of the intervention and inform the development of realistic indicator targets. A number of relevant monitoring and evaluation guides are referenced in the suggested further reading section below.

$\rightarrow$ Use a wide range of available data.

A host of quantitative and qualitative resources are publicly available to conduct micro-level analyses and evaluations at the output and outcome level, including conflict and insecurity data, crime rates, judicial statistics, public perceptions (as measured by opinion polls and focus groups), and reports by civil society organizations. ${ }^{13}$ Moreover, to measure the macro-level impact of interventions, it may be suitable to use global indicators to compare the performance of states with regards to governance, rule of law, or peace and conflict related issues. The suggested further reading section below presents a range of publicly available resources -including conflict and insecurity data as well as global indices - that can be used to design, plan, implement, and evaluate approaches to CBAGs.

\section{Coordination}

$\rightarrow$ Improve coordination and coherence among intervening actors.

It is not only important to address issues of local ownership and ensure coordination between intervening actors and local partners, but also to promote integration between intervening actors themselves. The lack of coherence and coordination among the multitude of actors involved in the EMT of CBAGs - development or humanitarian agencies, international organizations, and armed forces - can have serious repercussions for both the overall outcome of interventions and the application of lessons learned by other organizations, in different contexts. It is therefore imperative for all actors to closely coordinate interventions and their impact evaluation across geographical and institutional boundaries.

\section{$\rightarrow$ Harmonize reporting requirements.}

Humanitarian and development actors currently use countless formats to report on progress and impact of their interventions. Simplifying and harmonizing reporting practices is one of the main goals of the Grand Bargain, an agreement between large donors and humanitarian organizations to improve the effectiveness and efficiency of aid delivery. ${ }^{14}$ To reduce the administrative burden for implementers and standardize terminology across the sector, the

13 Mark Sedra, "Adapting Security Sector Reform to Ground-Level Realities: The Transition to a Second-Generation Model," Journal of Intervention and Statebuilding 12, no. 1 (2018): 48-63.

14 "The Grand Bargain," Inter-Agency Standing Committee, accessed March 31, 2020, https://interagencystandingcommittee. org/grand-bargain 
harmonized " $8+3$ " reporting template represents a useful tool to reduce the reporting burden for partners, while providing the necessary information for donors. ${ }^{15}$

\section{Indicators}

$\rightarrow$ Take politics into account

Approaches to CBAGs are hardly purely technical in nature; as such, their evaluation needs to take local politics into account. For instance, failures to address political dynamics in the integration of CBAGs into state security forces, as was the case with Mai Mai in eastern Democratic Republic of Congo, have shown that SSR is as much a political process as a technical approach. ${ }^{16}$ Indicators that measure progress against targets should reflect this reality and focus on political as well as technical aspects of the intervention. ${ }^{17}$

$\rightarrow$ Use locally adapted indicators

Just as intervening actors should use locally adapted approaches to CBAGs, they should also use locally adapted measures of success that reflect contextual variation and focus on the predominant functions of targeted CBAGs, following thorough context analysis and actor mapping. The Everyday Peace Indicators research approach ${ }^{18}$ or the country-led approach to Governance Indicators in Justice and Safety at the Harvard Kennedy School ${ }^{19}$ provide useful guidelines on how to develop locally adapted indicators.

\section{$\rightarrow$ Use transferable indicators}

While it is crucial to use locally adapted indicators as per the previous recommendation, whenever feasible, it is preferable to have a set list of standard indicators that are applicable across contexts to allow for comparability between interventions. Table 1 below shows a set of specific indicators that intervening actors could use across contexts to measure the progress of interventions in meeting their objectives. More resources on key performance indicators can be found in the suggested further reading section below.

Although the overall goal of approaches towards CBAGs is an improvement in community security for the populations living in areas where CBAGs are present, each approach has

15 The reporting template is called the ' $8+3$ template' for the maximum number of questions donors should request in any report. See Inter-Agency Standing Committee, Harmonized Reporting Template (8+3 template), Septem-

ber 13, 2019, https://interagencystandingcommittee.org/harmonize-and-simplify-reporting-requirements/

harmonized-reporting-template-83-template-final

16 Maria Eriksson Baaz and Judith Verweijen, "The Volatility of a Half-Cooked Bouillabaisse: Rebel-Military Integration and Conflict Dynamics in the Eastern DRC," African Affairs 112, no. 449 (2013): 563-82.

17 Paul Jackson and Shivit Bakrania, "Is the Future of SSR non-linear?," Journal of Intervention and Statebuilding 12, no. 1 (2018): 11-30.

18 See Everyday Peace Indicators, a nonprofit charitable organization registered in the United States: Everyday Peace Indicators, accessed March 31, 2020, https://everydaypeaceindicators.org/

19 See "Indicators in Development: Safety and Justice" Malcolm Wiener Center for Social Policy, John F. Kennedy School of Government, Harvard University, accessed March 31, 2020, https://www.hks.harvard.edu/centers/wiener/programs/ criminaljustice/research-publications/indicators-in-development-safety-and-justice 
its specific objective. Engagement focuses on ensuring safe access for intervening actors to areas with CBAGs; coercive management aims to reduce the reach and legitimacy of CBAGs; cooperative management strives to improve the treatment of local populations by CBAGs; and transformation aspires to render CBAGs obsolete for their members, sponsors, and communities.

Table 1 proposes two specific indicators each to measure the progress in achieving the overall goal and the four objectives. For instance, a program seems to be on the right track to achieve improved community security if data show an increase in the percentage of the population perceiving security in their communities and a decrease in the number of violent incidents reported in the communities.

Table 1: Indicators to Measure Results of Different Approaches to CBAGs

\section{Results}

\section{Goal:}

Improved community security for population living in areas with CBAGs

\section{Objective 1 (Engagement):}

Safe access for intervening actors to areas with CBAGs

\section{Objective 2 (Coercive Management):} Reduced reach and legitimacy of CBAGs

Objective 3 (Cooperative Management): Better treatment of population in local communities by CBAGs

\section{Objective 4 (Transformation):} Obsolescence of CBAGs for members, sponsors, and communities

\section{Indicators}

Indicator 1: Percentage of population perceiving (in)security in their community Indicator 2: Number of violent incidents reported

Indicator 1.1: Percentage of staff of humanitarian and development actors perceiving safe access to areas with CBAGs

Indicator 1.2: Number and frequency of attacks on staff members of humanitarian and development actors

Indicator 2.1: Number of people living in communities with CBAGs

Indicator 2.2: Percentage of population perceiving CBAGs as legitimate

Indicator 3.1: Percentage of population perceiving CBAGs as positive and constructive forces in communities Indicator 3.2: Number of reported incidents of abusive behavior by CBAGs to communities

Indicator 4.1: Number of members of CBAGs Indicator 4.2: Percentage of population perceiving state security provision as sufficient within communities

\section{Conclusion}

Source: Author

This Policy Note provided recommendations on how to better measure the progress of EMT approaches against their objectives. Before designing and implementing any interventions, it is crucial to plan and conduct assessments, such as context analysis and actor mapping, baseline studies and impact evaluations. It is also recommended to use a wide range of publicly available data to set indicator targets and measure progress against objectives, both at the macro and micro level. When defining measures of success, it is important to take political dynamics into account and to ensure a good balance between locally adapted indicators and transferable indicators that are comparable across contexts. To improve comparability and application of lessons learned, it is equally important for intervening actors to coordinate their efforts to measure the success of their projects and to reduce duplication of efforts, for instance by harmonizing reporting requirements. 


\section{Suggested Further Readings, by topic}

\section{On Guidance for Monitoring and Evaluation}

Seethaler, Franziska. Assessing the Impact of DDR Programmes: Possibilities and Challenges. New York: United Nations University, 2016. https://collections.unu.edu/eserv/UNU:5546/Assessing Impact of DDR Programmes 160322.pdf

Mattei, Cristina, and Sara Zeiger. Evaluate Your CVE Results: Projecting Your Impact. Abu Dhabi, UAE: Hedayah, 2018. https://www.hedayahcenter.org/resources/reports and publications/ evaluate-your-cve-results-projecting-your-impact/

Holdaway, Lucy, and Ruth Simpson. Improving the Impact of Preventing Violent Extremism Programming: A Toolkit for Design, Monitoring and Evaluation. Oslo: United Nations Development Programme, 2018. https://www.undp.org/content/dam/undp/library/Global\%20Policy\%20Centres/OGC/PVE ImprovingImpactProgrammingToolkit 2018.pdf

Holmer, Georgia, Peter Bauman, and Kateira Aryaeinejad. Measuring Up: Evaluating the Impact of P/ CVE Programs. Washington, DC: United States Institute of Peace, 2018. https://www.usip.org/ publications/2018/09/measuring-monitoring-and-evaluating-pcve-programs

\section{On Key Performance Indicators}

Agoglia, John, Michael Dziedzic, Barbara Sotirin. "Measuring Progress in Conflict Environments." - United States Institute for Peace,2010: https://www.usip.org/sites/default/files/MPICE final complete\%20 $\underline{\text { book\%20(2).pdf }}$

Gowen, Claire. "Security Sector Governance and Justice Indicators Guide." United States Agency for International Development (USAID). June 2019. https://www.usaid.gov/sites/default/files/documents/1866/ SSG-and-Justice-Indicators-Guide-6-2019.pdf

International Dialogue on Peacebuilding and Statebuilding. "Peacebuilding and Statebuilding Indicators - Progress, Interim List and next steps." Third International Dialogue Global Meeting: The New Deal: Achieving Better Results and Shaping the Global Agenda. Washington, D.C. April 19, 2013. https://www.pbsbdialogue.org/media/filer public/a1/52/a152494f-0bb0-4ff3-8908-14bb007abd25/ psg indicators en.pdf.

United Nations Statistics Division. "Sustainable Development Goal 16 Indicators." E-Handbook on SDG Indicators. Accessed March 31, 2020. https://unstats.un.org/wiki/display/SDGeHandbook/Goal+16.

UN Office of the High Commissioner for Human Rights and UN Department of Peace Operations. "United Nations Rule of Law Indicators: Implementation Guide and Project Tools." United Nations, 2011. https://www.un.org/en/events/peacekeepersday/2011/publications/un rule of law indicators.pdf.

World Bank. "Post-Conflict Performance Indicators: Assessment Questionnaire." Operations Policy and Country Services. Accessed March 31, 2020. http://pubdocs.worldbank.org/en/310751531314751676/ PCPIcriteria.pdf.

\section{On Conflict and Insecurity Data}

Armed Conflict Location \& Event Data Project (ACLED). Accessed March 31, 2020. https://www.acleddata. $\underline{\mathrm{com} / .}$ 
PAX Protection of Civilians. "Human Security Survey Iraq." Accessed March 31, 2020. https://protectionofcivilians.org/projects/hss-iraq/

PAX Protection of Civilians. "Human Security Survey South Sudan." Accessed March 31, 2020. https://protectionofcivilians.org/projects/hss-south-sudan/

Small Arms Survey. Accessed March 31, 2020. http://www.smallarmssurvey.org/.

The Humanitarian Data Exchange (HDX). Accessed March 31, 2020. https://data.humdata.org/.

Uppsala Data Conflict Program (UDCP). Department of Peace and Conflict Research. Accessed March 31, 2020. https://ucdp.uu.se/.

\section{On Global Indices}

The Fund for Peace. "Fragile States Index." Accessed March 31, 2020. https://fragilestatesindex.org/.

Heidelberg Institute for International Conflict Research (HIIK). "Conflict Barometer." Accessed March 31, 2020. https://hiik.de/conflict-barometer/current-version/?lang=en.

Institute for Economics and Peace. "Global Peace Index." Vision of Humanity. Accessed March 31, 2020. http://visionofhumanity.org/indexes/global-peace-index/.

Mo Ibrahim Foundation. "Ibrahim Index of African Governance (IIAG)." Accessed March 31, 2020. http:// iiag.online/.

World Bank. "World Governance Indicators." Accessed March 31, 2020. http://info.worldbank.org/ governance/wgi/.

World Justice Project. "Rule of Law Index." Research and Data. Accessed March 31, 2020. https://worldjusticeproject.org/our-work/wjp-rule-law-index.

\section{Sources}

Baaz, Maria Eriksson, and Judith Verweijen. "The Volatility of a Half-Cooked Bouillabaisse: Rebel-Military Integration and Conflict Dynamics in the Eastern DRC." African Affairs 112, no. 449 (2013): 563 82. https://doi.org/10.1093/afraf/adt044.

Dietrich, Kyle. "When We Can't See the Enemy, Civilians Become the Enemy" - Living Through Nigeria's SixYear Insurgency. Washington, DC: Center for Civilians in Conflict, 2015. https://civiliansinconflict. org/wp-content/uploads/2015/10/NigeriaReport Web.pdf.

Gundel, Joakim. Humanitarian Action in the New Security Environment: Policy and Operational Implications in Somalia and Somaliland. London: Overseas Development Institute, 2006. https://www. odi.org/sites/odi.org.uk/files/odi-assets/publications-opinion-files/389.pdf.

Jackson, Paul. "Introduction: Second-Generation Security Sector Reform." Journal of Intervention and Statebuilding 12, no. 1 (2018): 1-10, https://doi.org/10.1080/17502977.2018.1426384.

Jackson, Paul, and Shivit Bakrania. "Is the Future of SSR non-linear?". Journal of Intervention and Statebuilding 12, no. 1 (2018): 11-30. https://doi.org/10.1080/17502977.2018.1426548.

Kiyala, Jean Chrysostome. "Utilising a Traditional Approach to Restorative Justice in the Reintegration of Former Child Soldiers in the North Kivu Province, Democratic Republic of Congo." Africa Insight 
46, no. 3 (2016): 33-50, https://journals.co.za/content/journal/10520/EJC-6527bbc41.

Lamb, Guy. "Police Militarisation and the 'War on Crime' in South Africa." Journal of Southern African Studies 44, no. 5 (2018): 933-49. https://doi.org/10.1080/03057070.2018.1503831.

Muggah, Robert, and Chris O'Donnell. "Next Generation Disarmament, Demobilization and Reintegration." Stability: International Journal of Security \& Development 4, no. 1 (2015): Art. 30. https:// doi.org/10.5334/sta.fs.

Munive, Jairo, and Finn Stepputat. "Rethinking Disarmament, Demobilization and Reintegration Programs." Stability: International Journal of Security \& Development 4, no. 1 (2015): Art. 48. https:// doi.org/10.5334/sta.go.

Planta, Katrin, and Véronique Dudouet. Fit for Negotiation? Options and Risks in the Political Transformation of Non-conventional Armed Groups. Oslo: Norwegian Peacebuilding Resource Centre (NOREF), 2015. http://www.clingendael.nl/publication/violence-politics-transforming-non-conventional-armed-groups.

Schuberth, Moritz. Approaching Community-Based Armed Groups in Sub-Saharan Africa: Lessons Learned \& Measures of Success. Washington, DC: RESOLVE Network, 2019. https://www.resolvenet.org/ research/approaching-community-based-armed-groups-sub-saharan-africa-lessons-learnedmeasures.

- - - "The Challenge of Community-based Armed Groups: Towards a Conceptualization of Militias, Gangs, and Vigilantes." Contemporary Security Policy 36, no. 2 (2015): 296-320. https://doi.org/1 $0.1080 / 13523260.2015 .1061756$.

- - - "Disarmament, Demobilisation and Reintegration in Unconventional Settings: The Case of MINUSTAH's Community Violence Reduction." International Peacekeeping 24, no. 3 (2017): 410-33. https://doi.org/10.1080/13533312.2016.1277145.

Sedra, Mark. "Adapting Security Sector Reform to Ground-Level Realities: The Transition to a SecondGeneration Model." Journal of Intervention and Statebuilding 12, no. 1 (2018): 48-63. https://doi. org/10.1080/17502977.2018.1426383.

Zahar, Marie-Joëlle, and Delphine Mechoulan. Peace by Pieces? Local Mediation and Sustainable Peace in the Central African Republic. New York: International Peace Institute, 2017. https://www.ipinst. org/wp-content/uploads/2017/11/1701 Peace-by-Pieces.pdf. 


\section{About the Note}

Author: Dr. Moritz Schuberth

Moritz Schuberth is a Visiting Fellow at the Centre for Public Authority and International Development at the London School of Economics and Political Science. He has extensive experience managing projects and conducting research in fragile and conflict-affected settings, including over the past three years for the global humanitarian agency Mercy Corps in the eastern Democratic Republic of the Congo. Moritz has published widely on peacekeeping, nonstate armed groups, security governance, and organized crime. He consults the U.S. government on stabilization operations and his research on cultural cognitive diversity has been used to train U.S. special forces.

The views expressed in this publication are those of the author. They do not necessarily reflect the views of the RESOLVE Network, the U.S. Institute of Peace, or any entity of the U.S. government.

\section{RESOLVE NETWORK}

better research.informed practice.improved policy on violent extremism.

www.resolvenet.org

(A) in 